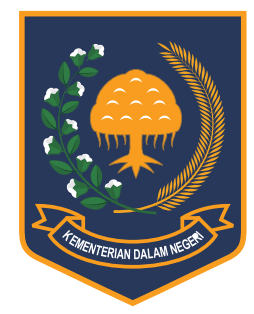

Jurnal Bina Praja 9 (2) (2017): 185 - 193

Jurnal Bina Praja

e-ISSN: 2503-3360 | p-ISSN: 2085-4323

Accreditation Number

735/AU2/P2MI-LIPI/04/2016

http://jurnal.kemendagri.go.id/index.php/jbp/index

\title{
Social Process of Ethnicity in URban Area: Case Study Between Chinese Ethnic AND Sundanese EThNiC In Bandung City
}

\author{
Mohammad Mulyadi * \\ Research Center of the Expertise Agency of House of Representatives of the Republic of Indonesia \\ MPR/DPR RI Nusantara 1 Building Paripurna, 2nd Floor \\ Jl. Jenderal Gatot Soebroto, Central Jakarta
}

Received: 16 August 2017; Accepted: 13 September 2017; Published online: 28 November 2017

DOI: $10.21787 /$ jbp.09.2017.185-193

\begin{abstract}
A city with a multicultural society allows the social processes of ethnicity, either associative or dissociative. Especially in the city of Bandung, the dynamics of social processes of ethnicity between Chinese ethnic and Sundanese ethnic have ups and downs. Based on the idea, the purpose of this study is to describe how the associative and dissociative social process of Chinese ethnic and Sundanese ethnic in Bandung? The research design uses a qualitative approach with case study model. The location of the research was conducted in Bandung. This research produced a description of social relations practices that are associative in the form of cooperative relations if there is a common interest, while in the form of accommodation occurs if the Chinese ethnic embraces Islam. The social process in the form of assimilation and amalgamation can be seen in the field of culture. Meanwhile, social processes that indicate competition, rivalry, and social conflict (dissociative) start from the perspective of stereotypes, prejudices and discriminatory.
\end{abstract}

Keywords: Social, Ethnicity, Ethnic, Chinese, Sundanese

\section{INTRODUCTION}

A social process is any social interaction that takes place over a period of time, in such a way to show the patterns of repetition of behavioral relationships in people's lives. Broadly speaking, the social process can be divided into two types, namely associative and dissociative social processes. An associative social process occurs when the interaction process that occurs in the community indicates an approach and an integration, while a dissociative social process is when the interaction process that occurs in the community indicates the existence of competition, rivalry, and social conflict (Siti Norma in Narwoko and Suyanto 2010, 57-58).

Furthermore, according to Siti Norma, there are four special forms of associative social process, namely: cooperation, accommodation, assimilation, and amalgamation. Meanwhile, a dissociative social process is divided in the form of competition and conflict. As for the definition of various forms of social process, it is as follows: cooperation is cooperating. Accommodation is a process towards achieving a mutually acceptable agreement. Assimilation is a process of cultural melting. Amalgamation is a process of cultural fusion so there are no more contradictions between groups. Competition is a competition between two groups. A conflict is a person or group that challenges each other with threats (Siti Norma in Narwoko and Suyanto 2010, 58-68).

Bandung City is one of the cities in Indonesia that has a society with a very complex level of diversity. Chinese ethnic is one ethnic that colors the diversity of ethnics in Bandung.

Trading is one of Chinese ethnic's skills. Trading activity in Pasar Baru of Bandung City is a proof that Chinese ethnic is quite skilled in trading. This market has existed since the Dutch colonial era and has even been crowned as the best market in the Dutch East Indies. This market has also been renovated in 1970 while market modernization was

\footnotetext{
* Corresponding Author

Phone : +628124160116

Email : mohammadmulyadi@yahoo.co.id
} 
implemented in 2007.

According to Soegijoko (2011), a city is the center of national or local activities that acts as the center of manufacturing industry, or as the center of service activities. Because it acts an industrial center, a city has the lure of livelihood in search of a more decent life. As a result, the city becomes the goal of many people who come from various ethnics and cultures. Diversity or difference of a culture with another culture is what is called as multicultural.

Cities with multicultural societies allow for social interaction with polarization by ethnic or social class. Polarity can then form a social process and the dynamics of society, both of which are associative or dissociative.

According to Saragih (2008), in Indonesia, the ethnicity that is considered to have a fairly thick ethnocentrism is Chinese ethnic. Wherever they are, they tend to show ethnocentrism. However, the facts on the ground show the social process of ethnicity that occurs between Chinese ethnic and Sundanese ethnic has a long history since Sundanese people and Chinese people like each other. This can be seen from a very sticky relationship, like two inseparable tribes from one another, mutual benefit, mutual trust, and all other positive things. This is what drives the author (curiosity) to conduct a research in the midst of tidal relations between Chinese ethnic and various other ethnics in the country.

Several studies that have been conducted are studies in Luwu Regency, South Sulawesi Province stating that the relationship between ethnic groups is not always of negative connotations, but also can be positive if the relationship is well-managed so as to enable the creation of a harmonious social order in a new society. Conversely, inter-ethnic conflicts can occur when they are not properly managed (Basir, 2011).

As for the study conducted by Hasbullah in Bengkalis Regency of Riau Province, the relationship between Chinese ethnic and indigenous people is good enough because of a mutualistic cooperation. However, this condition only occurs in the economic sector and has not involved other significant parts of life. In that connection, it also created a stereotype as a continuation of the colonial legacy that has placed Chinese ethnic as a middle class. This resulted in the social jealousy of the indigenous groups, especially those sourced from economic disparities. This is something that is handled seriously and cautiously by various parties, especially in this era of reform, democracy, and transparency (Hasbullah, 2013).

The above text wishes to show that legally and socially, a discrimination against Chinese in Indonesia is a product of the interaction between the dominance of the indigenous Indonesians' nationalist ideology at the national level with Chinese ethnicity as foreign, in the contexts of resource competition and seizures.

Chinese citizens in their interaction with the wider community are still regarded as inclusive and closed in the midst of ethnic diversity in Indonesia. The attitude to self-exposure can be seen from the schools they founded in which most and even all of the students come from Chinese ethnicity. The closed-off attitude as shown by Chinese ethnic can be seen from strong, sealed trellises that are installed in their houses. Therefore, exclusive and closed are the impression that can be seen among Chinese ethnic in Bandung City.

In addition, "Chinese ethnic still often set the distance to interact with other ethnic groups in Bandung City, one example is that Chinese ethnic prefers to hang out or look together with other Chinese ethnic. It is not without reason because Chinese ethnic consider the majority of ethnic groups do not consider them as citizens" (interview with Jesslyn, ethnic Chinese working as Public Relations of Masjid Lautze Kota Bandung, interview June 19, 2014). In this connection, the importance of the role of government as the party expected to be able to formulate and implement the policy of social harmony management in relations among ethnic groups as an integrative part in regional development.

Based on various phenomenon of social process of ethnic that happened between Chinese ethnic and Sundanese ethnic in Bandung City, hence the researcher is interested to research and deepen about social process that happened, both associative and dissociative, with problem formulation: How are the associative and disassociative social processes of Chinese ethnic and Sundanese ethnic in Bandung City?

The purpose of this study is to provide a description of the social process between Chinese ethnic and Sundanese ethnic in Bandung City that tookplace in residential and workplace environment; in the form of Chinese ethnic and Sundanese ethnic behavior patterns in cooperation, accommodation, assimilation, amalgamation, competition, conflict, and contravention.

\section{METHOD}

This research is descriptive with a view to exploration and clarification about a phenomenon or a social reality. Meanwhile, the research strategy uses case study, where the purpose of using case study research is not just to explain how the object under study is, but also to explain how the existence and why the case can occur. The research that includes observation and interview activities was conducted in Bandung City, West Java Province. This research activity time was in June 2014. The reason for choosing the location of research in Bandung is because Bandung has a long history of the 
relationship between Chinese ethnic and Sundanese ethnic.

The data collection is done by giving priority to the informant's perspective (perceptive emic), and the researcher himself acts as the main instrument (key instrument) that goes directly to the field to collect the data in depth. This is in accordance with the opinion of Bogdan \& Biklen (1982) that: "Qualitative research has the natural setting as the source of data and researcher is the key instrument." The informants interviewed in this study are of Chinese ethnic and Sundanese ethnic in Bandung City.

The data analysis uses qualitative analysis. In operation, the qualitative data analysis is the process of compiling data (classifying them in themes or categories) in order to be interpreted. In principle, this analysis is performed at any time during the study. The data collection and data analysis activities in this study are not separated from each other. Both take place simultaneously and the process is cyclical (Creswell, 1994).

\section{RESULTS AND DISCUSSION}

\section{A. Analysis of Associative Social Process of Chinese Ethnic and Sundanese Ethnic in Bandung City}

According to Siti Norma in Narwoko and Suyanto (2010, p. 57) Associative social process can be seen from various forms, namely: cooperation, accommodation, assimilation, and amalgamation. The research conducted in Bandung shows various patterns of relationships that occur between Chinese ethnic and Sundanese ethnic. Here are the results of research and discussion.

\section{1) Cooperation}

Cooperation is a situation where Chinese ethnic and Sundanese ethnic is in an interaction to jointly work together in order to achieve common goals. Chinese ethnic with the economic behavior is, realized or not, actually has donated various cooperations in economic activities of the Indonesia nation. As noted by Fujitsu Research in Tokyo which looks at the list of companies in 6 key countries in Asia, it describes how those companies are majority dominated by overseas Chinese ethnic groups, for example, Thailand as much as $81 \%$, Singapore is $81 \%$, and in Indonesia as much as $73 \%$, and so on (Naisbitt, 1994).

The above picture proves how influential the role of Chinese ethnic economy in the economy of Indonesia. In Bandung, according to one Chinese citizen, "a cooperative relationship occurs when there is a common interest, it can be seen in the relationship between business owners/shops by
Chinese ethnic and employees who are usually from Sundanese ethnic" (interview with Yang Jin Zen, June 17, 2014). The statement is reinforced by one of the employees of a shop in Bandung who is of Sundanese ethnic and has been working for the store for decades and is trusted by the owner, he said "Tionghoa shopkeepers will strongly believe in an employee if the interests of the shopkeeper can be fulfilled, for example, the store employee can give an advantage on every buying activity at the store (interview with Suryanap a shopkeeper June 20, 2014). According to Charles H Cooley, as quoted by Soekanto (2010), Cooperation arises when people realize that they have the same interests and at the same time have enough knowledge and self-control to meet those interests.

Therefore, the cooperation relationship between Chinese ethnic and Sundanese ethnic should be maintained not only because of the same interests but also because of the existence of the two tribes, mutual needs, and mutual trust in the social order of multi-ethnic life.

\section{2) Accommodation}

Accommodation is a process in social relations leading to adaptation so that Chinese ethnic and Sundanese ethnic relations are intertwined to cope with tensions. According to Soekanto (2010), the term accommodation is used in two meanings, namely as a condition and a process. As a condition, accommodation means the existence of a balance (equilibrium) of relationships between individuals or groups in interacting with respect to prevailing social and cultural norms. As a process, accommodation means a human effort to defuse or avoid conflict in order to achieve stability.

In this study, the researcher found that social adaptation process conducted by Chinese ethnic, especially those who have embraced Islam, gave birth to a pattern of social adaptation. The pattern of social adaptation can be seen from the way Chinese Muslims adapt to their non-Muslim families, as for the way they perform such adaptations, namely: (1) intensive communication for their non-Muslim families. Although in several interviews with resource persons, the method has not been effective. But they (Chinese Muslim) remain in an intense communication. (2) Provide an understanding of their beliefs (Islam) to non-Muslim families. This is because of a kind of negative stigma against Islam that is done by some Tionghoa ethnic. (3) Mix in their cultural activities (Chinese ethnic). Because in general, the rejection of some Chinese ethnic community against members of their family, who embraced Islam, is more to the attitude of Chinese Muslim exclusivism. Because sometimes the fanaticism of culture or custom can defeat the fanaticism of religion (Interview with Jesslyn, 
Chinese ethnic who works as a Public Relation of Lautze Mosque in Bandung City, interviewed on June 17, 2014).

The social adaptation made by Chinese Muslims to their non-Muslim families is one example that every human being needs recognition from his social environment since no human can live alone without the help of other human beings. Therefore, every human being will strive for his acceptance in a social environment.

Whatever they do certainly, other than as a means of making a living, is also an attempt to conquer and adapt to the conditions and social situations in an overseas place in accordance with the capabilities they have. The business they do is to open the shop selling the daily needs of the people (sembako) and make food, such as meatballs, chicken noodles, otak-otak (fish cake), cakes for Lunar New Year, and cookies for the Muslim Eid Al-Fitr. According to Suparlan (2008), the history records the Chinese ethnic social life with indigenous people in the neighborhood was, in the past, very harmonious and unpretentious. The Chinese ethnic in the past was the ethnic group which upheld the philosophy of life, 'where the earth is rested, there the sky is upheld.' Because of that philosophy, in the past, there was almost no conflict between the local community and the Chinese Ethnic.

\section{3) Assimilation}

Assimilation is an attempt to reduce the differences between individuals and groups of people and also to include efforts to enhance unity of actions, attitudes, and mental processes by noticing common interests and goals.

The condition of the life of Chinese ethnic in Bandung City itself during the reign of President Soeharto is not much different from the previous period. It can even be said to be more stringent. The government issued Presidential Instruction Number 14 of 1967 on the prohibition of mandarin use and script in the mass media and in the name of the store or company. The names of stores or locations using Chinese should be changed to Indonesianlanguage names. As the name change, Xie Tian Gong Temple becomes Satya Budi Temple. This applies also in performing worship. The ethnic Chinese can only perform in their own homes. The purpose of the government issued Presidential Instruction Number 14 of 1967 is to conduct total assimilation against foreign ethnics in Indonesia, especially Chinese ethnic. Some Chinese ethnic accepted the government's proposal for assimilation by supporting the assimilation charter in Bandungan in 1961. Others chose to preserve the ancestral culture and demand that the Chinese be recognized as one of the indigenous ethnic groups in Indonesia (Dewi, 2015).
The New Order government born under the leadership of President Soeharto decided that there was only one way to solve the Chinese problem, which was through the process of assimilation (Wibowo, 1999). This solution is also used as a national solution as reflected in various regulations issued by the government at that time regarding the Chinese ethnic community. All is done so that the Chinese ethnic community can be assimilated well and the prejudice against them is reduced.

The birth of Law of the Republic of Indonesia Number 12 of 2006 on Citizenship and Law of the Republic of Indonesia Number 40 of 2008 on the Elimination of Racial and External Discrimination is the basis of the government's efforts and commitment to providing protection, certainty, and equality of law in all citizens to live free from racial and ethnic discrimination (Susanti, 2007).

At that time all forms of Chinese culture in Indonesia were prohibited, Barongsai art was destroyed and should not be played again. Then after the end of the New Order and into the Reform Era, the Barongsai art began to wriggle again. Since then, many lion dances have reappeared, even now the Barongsai art is not only played by young Chinese, but many indigenous Indonesians play it. In social and political realities, some people in the indigenous society consider local ethnic Chinese to remain "outsiders" whose nationalism is doubted and cannot be assimilated.

This backfires to all parties where it is certain that Chinese ethnic will feel threatened and there is no other option to withstand their communal solidarity as an oppressed minority. Therefore, the assimilation that takes place certainly cannot be separated from various factors inhibiting assimilation itself. Factors inhibiting/blocking assimilation include differences in physical characteristics, lack of knowledge about culture, feelings of fear of the power or culture encountered, and the isolation of life group in a society.

In contrast, according to Yang Jin Zen, "there are so many people of Chinese ethnic who are very proud to be Indonesian citizens, to loudly teach their children to love the country and scold their children when they do not know about Indonesia, even some children are scolded when not knowing about their country, and even scolded when they are unable to memorize national mandatory song. In essence, between the two ethnic groups, there is a desire to mingle and even unite, but on the Chinese ethnic side, they may be afraid of the past traumatic time. For Sundanese ethnic, Chinese ethnic is deemed as exclusive and unwilling to mingle, maybe the "distinction" in the bureaucracy was created from the impression of "exclusivity" so that Chinese ethnic naturally follow the path that formed. Despite being confused to find where the middle point is, but 
the friendly culture of Sundanese people is one of a very good and fast mixing process" (Interview with Yang Jin Zen, a Chinese ethnic citizen in Bandung, June 17, 2014).

In this research, the researcher found that the strength of assimilation tendency depends mainly on socio-cultural factors, not on the individual Chinese ethnic. This can be seen from the attitude of the people of Bandung, the majority of which come from Sundanese ethnic who are friendly enough in associating with anyone. So according to the researcher, one way to create harmony between different ethnics in the country is to adjust to the local culture by speaking in a local language. Therefore, we often find that when coming to Bandung, Chinese ethnic people speak in Sundanese. They use Sundanese not only to Sundanese but also to other Chinese people. The above-mentioned fact is different from Mackie's opinion that: "as a result of Dutch colonialism which divides the class of Indies citizens, putting Chinese ethnicity above the native peoples, resulting in the slow process Chinese assimilation to Indonesia" (Mackie, 1991). Even though the process of assimilating Chinese ethnic as Indonesians faces political, economic, and social discrimination, the solution of socio-cultural assimilation is a key answer to the Chinese ethnic assimilation problem in Indonesia.

\section{4) Amalgamation}

Amalgamation is the term of inter-ethnic mixed marriage, for example, Chinese ethnic and Sundanese ethnic. Amalgamation is commonly associated with cultural assimilation as it relates to the interaction between two different cultures.

The difference is the duration of settling and mixed marriages with the existing tribes are very influential on the values adopted. The full-blooded Chinese people were stronger in their Chinese tradition, which originated from their ancestors so that their deeds also have distinctive features compared to the crossbreed Chinese. Whereas in the crossbreed Chinese, the value of Chinese traditions derived from his ancestors has been fading, so that in certain cases, the characteristic is less prominent as a Chinese, but in certain things, characteristics still appear.

In discussing Chinese culture here, it does not matter whether it is a full-blooded or crossbreed Chinese culture. Instead, take the values that are still embraced and colored in their lives. Although there are differences, both have the same cultural roots that can be distinguished from other ethnic cultures, especially with Sundanese ethnic culture.

The diverse circumstance of Indonesian society, as well as its support for a more open mindset change, make mixed marriages between Sundanese ethnic and crossbreed Chinese ethnic become prevalent. Differences of cultural and religious values adopted by the bride and groom no doubt might raise legal issues between groups and if not resolved will lead to ethnic conflict.

Chinese ethnic with various cultures is, realized or not, in reality, has contributed a variety of cultural activities in Indonesia. Its "Chinatown" culture enriches the uniqueness of Indonesia's cultural treasures. To maintain safe and peaceful conditions in the pluralism of Indonesia, required a harmonious cultural relationship form. The existence of tolerance between ethnic groups through cultural appearance is a form of harmony that needs to be maintained

Mixed marriage according to Cohen (1979) is a marriage that takes place between individuals from different ethnic groups commonly called amalgamation. The existence of ethnic borders marked by the identity of each group causes marriage between tribes in Indonesia not easy to do. This often gets into trouble, partly because of the assumption that a person marrying a person outside of his or her own tribe will take a long time to make adjustments. Meanwhile, if a person marries a person in his or her own neighborhood, there will be no problem with the adjustment process (Hariyono, 1993).

In addition, the reluctance of someone to marry someone outside the tribe of his own people because of the differences in language. Indeed, both crossbreed Chinese ethnic and Sundanese ethnic are equally able to communicate in Indonesian, but not infrequently, if one party is conversing with a friend or relative who uses his own tribal language, then the partner feels offended.

According to Jesslyn, "Chinese people always expect their descendants to bring continuity of the clan and lineage uninterrupted, especially if the woman is Chinese, because as a daughter, she must follow her husband's clan, but at least it is expected to get a husband of the Chinese ethnic, since most of the time, their in-laws and children are required to continue the company that has been pioneered for many years by the family" (interview with Jesslyn, Chinese ethnic who works as a Public Relation in Lautze Mosque in Bandung, interviewed on June 19, 2014). The difficulty of inter-ethnic marriage is also sometimes based on ab excessive stereotype, where a certain party feels that only the person in his or her own tribe or group is worthier of marrying him, while the person outside his tribe is considered inappropriate. In this case, there is usually a madeup ethnic identity.

Apparently, people of Chinese descent in some areas are viewed by local indigenous people as exclusive (especially in the field of economics), so as to be less mixed with the surrounding community. While from the Chinese ethnic side, there is a 
growing view that marriage with non-Chinese is actually damaging the relationship of kinship for a family of Chinese descent. They underestimate the non-Chinese family, so it is not uncommon if there is a Chinese descent who marries a Sundanese; he is exiled by relatives of his own family. This invites other issues. Psychologically, there are obstacles due to differences in religion, economic capacity, and because of socio-cultural differences. Therefore, the marriage is considered illegitimate.

According to Jessyln, "inter-ethnic Chinese and Sundanese marriages can occur if those people love each other very strongly. Usually because of different races and religions, their relationship is opposed by all the female's families who happen to be of Chinese ethnic, but if the male is of Chinese ethnic, it is usually not too difficult to get a wife from the Sundanese ethnic" (interview with Jesslyn, a Chinese ethnic who works as a Public Relation in Lautze Mosque in Bandung, interviewed on June 19, 2014).

The insights of the descendants are wider because they are born from two different cultures. Chinese men who are married to Sundanese women consider their marriage as a profitable thing, rather than marrying Chinese women of their own. Politically, Chinese descent can take cover behind Sundanese people because they have the advantage of being indigenous. From an economic point of view, there is a symbiotic, mutual benefit. The Sundanese can improve their standard of living with trade skills, while the Chinese need protection and security.

\section{B. Analysis of Disassociative Social Process of Chinese Ethnic and Sundanese Ethnic in Bandung City}

Diversity is not unusual for Indonesians. There are at least 300 ethnic groups inhabiting the entire archipelago (Suryadinata, 2002). From a number of ethnic groups, in general, the nation of Indonesia is divided into two major groups of ethnic groups, namely indigenous ethnics such as Javanese, Sundanese, Bugis, Batak, and Minang, and immigrant ethnics such as Indian, Arabic, European (represented by Portuguese and Dutch), and Chinese.

In the field of religion, there are at least five religions that are officially recognized by the government, namely Islam, Protestant, Catholic, Buddhist, and Hindu as well as Confucianism. All of that is what constitutes a society that is included in the realm of the Republic of Indonesia. To maintain the safe and peaceful conditions in the pluralism of Indonesia required a harmonious relationship between groups. Ethnicity and religion by the Malinowsky Anthropologist (1982) are said to be two entities that until now when the world is stepping into the modern era, even postmodernism, will be one of the tapestries and tensions, the most effective reluctance among elements in society (Qodir, 2012).

The existence of tolerance between ethnics and interfaith religions is a form of harmony that needs to be maintained. However, some time ago (at least during 1998 and 1999) many events were very heartbreaking. The example of events that may have entered the black pages in Indonesian history are the events of May 1998 riots, the Maluku conflict, and more class-type conflicts. In the event of May 1998 , it showed the destruction that was done to all forms of ownership on behalf of Chinese ethnic (also included public facilities built by the government).

After the Independence Revolution, the tension of inter-indigenous and non-indigenous peoples' relations, especially those of Chinese ethnicity, re-emerged. This situation arose in the era of Parliamentary Democracy and Led Democracy. The politicians and the military, especially the antiCommunist army, suspect the relations between some Chinese ethnic communities with the Indonesian Communist Party (PKI) and the People's Republic of China (PRC), which at that time (1950) was controlled by the Chinese Communist Party (CCP). The proximity and the number of Chinese ethnic communities who are members of the Indonesian Citizenship Consultative Body (Baperki) and the PKI, and the PKI relations that often defend the interests of the Chinese ethnic community, are the indication. This is seen in anti-Chinese events in 1959, 1960 and 1963 (Wibowo, 1999).

\section{1) Competition}

Chinese ethnic with its economic behavior, realized or not, in fact, has contributed a variety of economic activities of the Indonesian nation, both positive and negative. Meanwhile, the culture of "Chinatown" enriches the uniqueness of Indonesian cultural treasures.

As noted by Fujitsu Research in Tokyo (Naisbitt, 1994), which observes at the list of companies in 6 key countries in Asia, it describes how these companies are majority dominated by overseas Chinese ethnic groups, for example, Thailand as much as $81 \%$, Singapore as much as $81 \%$, in Indonesia as much as $73 \%$, and so on.

The above illustration proves how influential the role of Chinese ethnic economy in the Indonesia economy. It has become a main provision or condition of the success of an economic development, that the economic participation of all parties must be free from the case of primordialism, including SARA in it. This becomes a problem in this paper. Because of the negative stereotypes about the Chinese ethnic economic role in society will disrupt economic growth, especially the negative stereotype 
associated with their economic role.

Another characteristic of Chinese ethnic in Indonesia is the willingness of hard work and habits of thrifty living. They are able to compete for a long time and rarely rest except for their big day. Always making money has become both their habit and pleasure (Mackie, 1991).

According to Garna that "more specifically, the competition seen in Bandung is the trade where Chinese ethnic controls more textile trade than the Sundanese ethnic. While in the food trade, Sundanese ethnics may be said to be more dominantly successful than Chinese ethnic. This is understandable because Sundanese people feel more secure when "hunting" culinary with the owner or chef cooked by Sundanese ethnic, as associated with halal eating and an ideal taste (interview with Prof. Judistira K. Garna, an Anthropologist of Unpad, June 18, 2014).

In contrast to this, Yan Jin Zen argues that "according to my knowledge, the competition in any field between any ethnic must exist, but to a reasonable extent it does not matter. And the number does not matter. A small example, I am a private tutor to students from different ethnic backgrounds, religions, etc. Knowing that my students who are of Sundanese ethnic compete in a soccer game with Chinese-majority Christian school is very exciting, but indeed the religious teachings and civil education make them able to respect each other "(interview with Yang Jin Zen, ethnic Chinese, June 17, 2014).

Thus, this research found that the competition between Chinese ethnic and Sundanese ethnic will always exist, especially in Bandung City where the polarization of trade type is divided into textiles type, which is controlled by Chinese ethnic, and foods type (culinary), which is controlled by Sundanese ethnic.

\section{2) Conflict}

Conflict is a social process between individuals or certain groups of people, due to a very basic difference of understandings and interests, resulting in a gap that impedes social interaction among those in conflict. Disputes, squabbling, and fighting (riot) are types of conflicts that often occur in the life of the community, therefore, if enabled, will be able to divide the order or social structure in society. In plural societies such as Indonesia, ethnic diversity has resulted in potential conflicts between nations and between governments and a civil society (Suparlan, 2003).

The series of conflicts in Indonesia involving Chinese ethnic have actually started since the colonial period first, the second decade of the 20th century, namely 1912 and 1918. 1912 riots took place in Surabaya and Surakarta. Six years after the riots, in 1918, anti-Chinese riots resumed in Kudus. The riots arose as a result of the conflicting interests of Chinese entrepreneurs with indigenous traders. As a result of the riots, several Chinese were killed, and many were injured. In addition to casualties, many Chinese houses were burned down (Suryadinata, 2002).

The peak of discriminatory acts against ethnic Chinese occurred in 1998 when the monetary crisis hit Indonesia. One of the targets of mass anger is the Chinese ethnic which is considered as the destroyer of the national economic system. The Chinese ethnic itself has always been the target of a communal hatred. In the riots of 1998, hundreds of houses and shops belonged to ethnic Chinese were burned, and many Chinese people left Indonesia.

Why ethnic riots occur in Indonesia and the answers may vary depending on who and what perspectives are used to see the issue. There are at least two answers that emerge based on the study of anthropologists to the events of ethnic riots in Ambon, Sambas-Singkawang, Medan, and Jakarta. Pelly (1994) concludes that ethnic riot is rooted in socioeconomic inequality and is a cultural protest that provides a strong indication that the social order in a pluralistic life has been violated and destroyed. The gap is the class-forming business of the New Order government regime that places certain ethnic groups of immigrants in the middle layer in the process of forming a local social pyramid. On the other hand, Suparlan (2008) used the dominant cultural analysis of Edward Bruner (1974), who implicitly argues that migrants' adjustment patterns in Ambon (i.e. Butonese, Bugis, and Makassar people) and Sambas (Madurese) have broken the rules of the game or social conventions built on the dominant cultural foundations of the local community.

The point of uneasiness begins, from the Chinese ethnic side from the ethnic racist attitude, the "as if" Chinese ethnic is not viewed as Indonesian, a "distinction" in the bureaucracy. If from the Sundanese ethnic side, inter-ethnic racial attitudes, Chinese ethnic apathy (but as far as I know, it is not apathetic, only unwilling to get into trouble with the major ethnic) (interview with Tan Goat Hian, a Chinese ethnic citizen in Bandung, June 18, 2014). One of the factors that make the conflict between Chinese ethnic and Sundanese ethnic in Bandung not protracted is the nature of compassionate Sundanese. The Sundanese prefer to settle differences through negotiation, rather than formally solving conflicts. This is consistent with Supriyatna's view that when there is a conflict between Sundanese ethnic and Chinese ethnic, Sundanese ethnic prefers to be settled in a kinship rather than formally resolved through legal or police channels (interview June 20, 2014). 


\section{Conclusion}

An associative social process in the form of cooperative relations in Bandung occurs if there is a common interest, this can be seen in the relationship between business owners/shops by Chinese ethnic with employees who are usually from Sundanese ethnic. The accommodation occurs in the Chinese ethnic more easily if the person embraces Islam.

The social process which indicates an approach and unification of Chinese ethnic and Sundanese ethnic (assimilation) can be seen in the cultural field, when the Chinese New Year is designated as a national holiday, Chinese ethnic begins to have the courage to display barongsai dance in public and Sundanese ethnic is no longer hesitating to join, mingle, watch, and even there are some people who come to give angpao on barongsai dance, take pictures, etc. Not only that, there are also many barongsai dancers who are of indigenous people and are interested in learning the art of barongsai, even make it their job. In terms of language, now many natives are interested in learning Mandarin, then they know Chinese culture and study it, even showing it in public. From an economic point of view, the relationship between Chinese ethnic and Sundanese ethnic has been very good and they respect each other. Indeed, there are some people who sometimes seem "racist" in hiring people, but until now there is no constraint.

The second fusion of ethnic (amalgamation) occurs mostly with mixed marriages, the conversion of religion, especially to Islam. From the cultural side, the two ethnic groups' cultures are not lost but the tolerance and the interest of each culture are followed by the two ethnic groups. For example, from mixed marriage alone, when married, all the customs of the wedding ceremony use Sundanese culture, but on the Lunar New Year, the Sundanese ethnic also celebrates it with all the equipment.

Meanwhile, social processes that indicate competition, rivalry, and social conflicts (dissociative) begins from a stereotypical, prejudicial and discriminatory perspective that often initiate a hatred and racial riot. of course, this perspective applies not only to the Chinese community in Indonesia but also to the other ethnic groups such as Batak, Minangkabau, Javanese, Sundanese, Madurese, Dayak, Bugis, Makassar and others who happened to stare in a certain area with a major ethnic group. From the socio-history point of view, the weight of each case is quite different. For the Chinese case in Bandung, for example, this stereotyped view is not infrequently addressed on the existential doubt of their status or position as one of the components of the nation. At this point, ideologically, it is also related to people's doubts about their national commitment. This worldview suspects the ethnic Chinese involvement in "determining" political economic processes to their involvement in power circles in the region and even the state.

In addition, one of the causes of ethnic conflict is a competition in the economic field, although certainly not all inter-ethnic conflicts are caused by economic problems alone. The level of availability of economic resources in a region becomes an important factor for the possibility of conflict. The easier the economic resources are earned by everyone, the less likely the conflict will occur. Conversely, the more difficult the availability of economic resources, the possibility of competition to obtain economic resources is bigger. Economic issues also concern the distribution of resources. Unclear rules in competition for resources are a potential source of conflict. In this case, the unclear rules can be interpreted as the possibility of injustice. The existence of social inequality as a result of a large economic gap is a reflection of the unfairness in the distribution of resources. If there is a big gap between various ethnic groups, then the possibility of conflict is also bigger, because the feeling of injustice will encourage the emergence of the spirit of resistance.

The most common ethnic conflicts in Indonesia involve Chinese ethnic and other ethnics as the holders of the initiative. Some conflicts show a wide and heavy scale, while others are smaller and local. The ethnic conflict between Chinese ethnic and indigenous ethnic groups is not always related to racial issues. This is evident from the fact that in general, the targets of riots and mass amok are in the form of destruction, looting, and arson of property rights, and not in the form of hostility towards ethnic Chinese and the killing of people, the conflict is further triggered by issues of economic domination and the welfare gap between Chinese ethnic and indigenous peoples.

In fact, Chinese ethnic is a quite successful ethnic in the economic field. They control most sectors of the economy and thus have large economic resources. Unfortunately, the success of the Chinese ethnic group does not coincide with the success of other ethnic groups in achieving economic progress. In other words, Chinese ethnic is able to win economic competition amidst the difficulties of economies in developing countries like Indonesia. In addition, the economic gap shown between Chinese ethnic and indigenous people is getting bigger from time to time. It is a fact that encourages the occurrence of conflicts that further indicates the existence of groups between Chinese ethnic and indigenous people. While ethnicity is not a source of conflict, it is the economic disparity that becomes the main source of conflict. 


\section{ACKNOWLEDGEMENT}

This research cannot be done without the help of many parties; therefore, the researcher would like to express his gratitude to several parties who have helped smoothen the research, from start to finish. Thanks to Jesslyn, a Chinese ethnic who workes as a Public Relation in Lautze Mosque, Bandung and Pak Suryanap, a citizen of Bandung who has helped to become the point of contact of some informants. Also, thanks to other informants who have taken the time to answer the various questions in this study.

\section{REFERENCES}

Basir, M. (2011). Hubungan Antar Suku Bangsa di Daerah Rawan Konflik (Kasus Desa Dandang dan Desa Kampung Baru Kab. Luwu Utara). Jurnal Al-Qalam, 17(2), 191-198. Retrieved from http://jurnalalqalam.or.id/index.php/ Alqalam/article/view/112

Bogdan, R., \& Biklen, S. K. (1982). Qualitative Research for Education: An Introduction to Theory and Methods. Allyn \& Bacon, Inc.

Creswell, J. W. (1994). Research Design Qualitative and Quantitative Approaches. Sage Publications.

Dewi, N. (2015). Romantika Tiga Zaman Kehidupan Masyarakat Keturunan Etnis Tionghoa di Kota Bandung pada Tahun 1960-2000. Universitas Pendidikan Indonesia. Retrieved from http:// repository.upi.edu/20176/

Hariyono, P. (1993). Kultur Cina dan Jawa: Pemahaman Menuju Asimilasi Kultural. Jakarta: Pustaka Sinar Harapan.

Hasbullah. (2013). Pola Hubungan Etnik Cina dengan Masyarakat Pribumi di Bengkalis. Jurnal Toleransi, 5(1 Januari-Juni), 23-32.

Mackie, J. A. C. (1991). Peran Ekonomi dan Identitas Etnis Cina Indonesia dan Muangthai. In W. G. Wu \& J. Cushman (Eds.), Perubahan Identitas Orang Cina di Asia Tenggara. Jakarta: Pustaka Utama Grafika.
Naisbitt, J. (1994). Global Paradox. Jakarta: Binarupa Aksara.

Narwoko, J. D., \& Suyanto, B. (Eds.). (2010). Sosiologi: Teks Pengantar dan Terapan. Jakarta: Kencana.

Pelly, U. (1994). Urbanisasi dan Adaptasi: Peranan Misi Budaya Minangkabau dan Mandailing. Jakarta: Pustaka LP3ES.

Qodir, Z. (2012). Involusi Politik Pemekaran, Etnisitas, dan Agama: Tantangan Reformasi Birokrasi Kasus Maluku Utara. Jurnal Bina Praja, 4(4), 217-226. http://doi.org/http:// dx.doi.org/10.21787/jbp.4.2012.217-226

Saragih, E. F. (2008). Dinamika Etnosentrisme Pria Etnis Tionghoa yang Menjalani Perkawinan Campur. University of Sumatera Utara. Retrieved from http://repository.usu.ac.id/ handle/123456789/23232

Soegijoko, B. T. S. (2011). Keterkaitan Antar Kota. In Bunga Rampai Pembangunan Kota Indonesia dalam Abad 21: Konsep dan Pendekatan Pembangunan Perkotaan di Indonesia (2nd ed.). Jakarta: Lembaga Penerbit Fakultas Ekonomi Universitas Indonesia.

Soekanto, S. (2010). Sosiologi Suatu Pengantar. Jakarta: Rajawali Pers.

Suparlan, P. (2003). Kesukubangsaan dan Posisi Orang Cina dalam Masyarakat Majemuk Indonesia. Jurnal Antropologi Indonesia, 71, 23-33.

Suparlan, P. (2008). Hubungan Antar-Sukubangsa. Jakarta: YPKIK.

Suryadinata, L. (2002). Negara dan Etnis Tionghoa: Kasus Indonesia. Jakarta: LP3ES.

Susanti, E. (2007). Asimilasi Etnik Cina dengan Melayu (Studi terhadap Mahasiswa Fakultas Ekonomi Universitas Islam Riau). Jurnal Sosial Budaya.

Wibowo, I. (Ed.). (1999). Retrospeksi dan Rekontekstualisasi Masalah Cina. Jakarta: PT. Gramedia. 